\title{
Membangun Percaya Diri Anak Panti Asuhan Melalui Kreativitas Majalah Dinding Sekolah
}

\author{
Martika Dini Syaputri, Ian Michael \\ Universitas Katolik Darma Cendika Surabaya
}

\begin{abstract}
Abstrak: Program Pengabdian Kepada Masyarakat yang diwujudkan melalui kegiatan Kuliah Kerja Nyata ini dilakukan di salah satu Lembaga Kesejahteraan Sosial Anak (LKSA) atau Panti Asuhan di Surabaya. Kegiatan yang dilakukan selama 3 (tiga) bulan dilakukan dalam rangka memecahkan masalah yang dihadapi oleh dampingan. Metode dalam menemukan akar masalah ialah dengan menggunakan analisis sosial serta melakukan wawancara secara mendalam dengan anak asuh, pengurus serta alumni. Pengalaman masa lalu yang buruk, lingkungan keluarga yang kurang baik, latar belakang yang tidak jelas maupun perlakukan yang berbeda ketika di masyarakat menjadikan dampingan kurang percaya diri. Bahwa percaya diri sangat berpengaruh untuk kesuksesan dimasa yang akan datang. Oleh karena itu, melalui program KKN ini, pendamping ingin membentuk rasa percaya diri dengan menggunakan media majalah dinding sekolah. Sehingga lingkungan sekolah akan memberikan respon yang positif bagi dampingan.
\end{abstract}

Kata Kunci : Panti asuhan, Percaya diri, Kreatif

Abstrack: Mentoring at the Community Service orphanage in Surabaya. Activities carried out for 3 (three) months to solve the problem at hand. The method used to solve problems with social analysis and in depth interviews to orphanages, management and graduate. Bad past experience, poor family environment, unclear background and different treatments when in the community make them less confident. That self-confidence is very influential for success in the future. Therefore, through this KKN program, we want to build self-confidence by using the school wall magazine media. So that the school environment will respond positively to them.

Keywords : Orphanage, Confidence, Creative 


\section{PENDAHULUAN}

Berdasarkan pada Undang-Undang Dasar Negara Republik Indonesia Tahun 1945 atau yang selanjutnya disebut UUD NRI 1945 di dalam Pasal 28 huruf a sampai huruf $\mathrm{j}$ memuat mengenai adanya perlindungan Hak Asasi Manusia (HAM) bagi setiap orang. Adanya perlindungan HAM bagi warga negara merupakan salah satu ciri bahwa Indonesia sebagai negara hukum. Jika dalam suatu negara, hak asasi manusia terabaikan atau dilanggar dengan sengaja dan penderitaan yang ditimbulkannya tidak dapat diatasi secara adil, maka negara yang bersangkutan tidak dapat disebut sebagai negara hukum dalam arti yang sesungguhnya. (Nurul Qamar, 2013)

UU No. 35 Tahun 2014 tentang Perubahan Atas Undang-undang No 23 Tahun 2002 tentang Perlindungan Anak yang selanjutnya disebut UU Perlindungan Anak merupakan wujud keseriusan pemerintah dalam melindungi segenap warga negaranya dari segala tindakan yang dapat merendahkan harkat dan martabat manusia. Anak merupakan kelompok lemah yang rentan menjadi korban pelanggaran HAM. Meskipun telah ada pengaturan mengenai perlindungan terhadap kekerasan anak, namun pada realitanya masih banyak terjadi kekerasan yang diterima oleh anak, baik kekerasan secara fisik, mental, seksual maupun psikologis.

Cacatan Tahunan Komisi

Perlindungan Anak Indonesia (KPAI) menunjukkan peningkatan kekerasan terhadap anak pada tahun 2018, yakni ada 4.885 kasus. Tempat yang dianggap aman bagi anak belum tentu menjamin anak dapat terlindungi HAMnya. Tempat pendidikan, tempat ibadah maupun rumah tempat tinggal pun bisa menjadi peluang terjadinya tindak kekerasan terhadap anak.

Salah satu kelompok yang rentan mengalami kekerasan (fisik, mental dan psikologis) adalah anak memiliki strata sosial yang berbeda dengan anak lainnya. Adanya ketimpanngan sosial dan ekonomi membuat anak yang tinggal di Lembaga Kesejahteraan Sosial Anak (LKSA) atau panti asuhan menjadi sasaran untuk mendapatkan kekerasan fisik maupun mental. Hal ini juga dialami dialami oleh anak yang tinggal di panti asuhan $\mathrm{X}$ di Surabaya. (nama LKSA tidak disebutkan atas permintaan pihak LKSA).

Berdasarkan pada aturan yang berlaku, bahwa LKSA mempunyai kewajiban untuk memberikan pelayanan pendidikan layak bagi anak asuhnya. Oleh sebab itu, para anak asuh disekolahkan sesuai dengan usianya yakni mulai TK hingga SMA/K anak-anak ini disekolahkan di beberapa sekolah yang letaknya tidak jauh dari panti asuhan. 
Stigma negatif masyarakat terdahap anak asuh masih cukup tinggi. Anak asuh selalu di identikkan dengan anak yang ada dalam lingkungan buruk, anak korban perceraian orang tua, anak yang tidak diinginkan oleh orang tuanya, anak terlantar maupun anak yang berhadapan dengan hukum. Sayangya Stigma tersebut sudah mulai menjalar di semua lini, tidak saja wali murid bahkan guru/tenaga pendidik dan teman sekolah pun sudah mulai memberikan stigma tersebut kepada anak asuh.

Kekerasan yang sering dialami oleh anak asuh di lingkungan sekolah menjadikan rasa percaya diri anak menjadi rendah, lebih banyak diam, berteman hanya dengan anak yang memiliki kesamaan dan menjadi sangat pemalu. Tentunya sikap-sikap yang ditunjukkan tersebut dapat menghambat berkembangan dalam akademik maupun non akademik.

\section{RUMUSAN MASALAH}

Berdasarkan pada latar belakang yang telah diutarakan diatas, maka dalam program pengabdian masyarakat ini, masalah yang akan kami bahas adalah: Bagaimana upaya membangun percaya diri anak yang tinggal di Lembaga Kesejahteraan Sosial Anak?

\section{METODE}

Kegiatan pengabdian masyarakat yang dikemas melalui program Kuliah Kerja Nyata (KKN) Universitas Katolik Darma Cendika dilakukan selama \pm 3 (tiga) bulan dilakukan di salah satu Lembaga Kesejahteraan Sosial Anak di Surabaya. (nama LKSA tidak disebutkan atas permintaan pengurus LKSA).

Beberapa tahapan yang dilakukan dalam program KKN antara lain melakukan analisis sosial untuk menemukan permasalahan serta impian/harapan dampingan dan melakukan Fokus Group Discussion (FGD) dengan dampingan maupun pengurus LKSA sebagai wadah untuk menyampaikan serta melakukan klarifikasi hasil analisis sosial yang telah dilakukan.

\section{HASIL PEMBAHASAN}

Program pengabdian masyarakat yang diwujudkan dalam bentuk KKN yang dilakukan pada salah satu LKSA di Surabaya berlangsung \pm 3 bulan. Langkah awal yang dilakukan adalah melakukan analisis sosial terhadap dampingan untuk mengetahui harapan serta permasalahan yang dihadapi oleh dampingan. Hal ini dilakukan sebagai upaya agar pelaksanaan KKN tepat sasaran atau program yang dibuat benar-benar dapat memecahkan permasalahan yang terjadi. Analisis sosial dilakukan melalui perjumpaan secara 
langsung, ikut berkegiatan dengan dampingan serta wawancara secara mendalam agar memperoleh informasi yang lengkap. Wawancara juga dilakukan dengan pengurus LKSA dan alumni yang pernah tinggal di LKSA tersebut.

Selama tinggal di LKSA, dampingan diajarkan tentang kediplinan, kerjasama dan mengasihi kepada sesama dan Tuhan yang diwujudkan dalam agenda harian yang wajib dilakukan mulai pagi hingga malam hari. Adapun jadwal kegiatan selama di LKSA antara lain dampingan bangun pukul 04.30 dan dilanjutkan doa pagi serta beberes tempat tidur. Setelah sarapan pagi yang telah disiapkan oleh pengurus, dampingan berangkat kesekolah dengan berjalan kaki mengingat jarak tempuh LKSA dengan sekolah tidak terlalu jauh. Pulang sekolah dampingan makan siang dan beristirahat hingga sore hari. Pukul 16.00 dampingan bangun dan melakukan bersih-bersih lingkungan LKSA yang dilakukan secara bersamasama.

Dampingan diharuskan belajar \pm 2 jam setiap harinya (minggu - kamis) dan diperbolehkan menonton televisi selain di hari tersebut. Dampingan juga wajib untuk mengikuti ibadah setiap hari Jumat dan Minggu di Gereja yang terletak tidak jauh dari LKSA. Dari kegiatan yang setiap hari dilakukan oleh dampingan, dapat disimpulkan bahwa pengurus telah menjalankan sesuai dengan aturan yang berlaku. Yakni mengutamakan pendidikan untuk dampingan.

LKSA memiliki aturan yang tidak boleh dilanggar oleh dampingan, antara lain: tidak diperbolehkan merokok, menggunakan narkoba, minum minuman keras, batas keluar malam hanya sampai dengan 21.00, tidak diperbolehkan memiliki alat komunikasi elektronik, tidak diperbolehkan pacaran dan diwajibkan untuk mengikuti seluruh kegiatan ibadah/gereja serta mementingkan belajar. Peraturan tersebut dibuat semata-mata untuk mendidik dampingan agar disiplin dan bertanggungnjawab.

Meskipun selama di LKSA dampingan telah didik dengan baik agar bisa diterima oleh masyarakat, namun penerimaan yang diterima tidak selalu baik termasuk ketika dampingan berada di sekolah. Hasil wawancara dengan pengurus diketahui bahwa dampingan memiliki permasalahan ketika berada di sekolah. Pengurus sering mendapatkan surat pemanggilan dari sekolah. Dampingan selalu dianggap bermasalah oleh pihak sekolah. Sedangkan ketika dilakukan konfirmasi, diketahui bahwa dampingan hanya dijadikan korban oleh teman-teman sekolahnya atas perbuatan yang tidak dilakukannya.

Hanya karena tinggal di panti asuhan dan tidak memiliki orang tua membuat dampingan selalu mendapat perlakuan 
yang berbeda baik oleh guru maupun temannya. Bahkan dianggap bahwa anak yang tinggal di LKSA adalah anak yang memiliki masalah dan buruk. Stigma negatif dari orang lain inilah yang membuat rasa percaya diri dampingan rendah yang berdampak pada menurunya prestasi akademik di sekolah.

Selain perlakuan yang berbeda ketika di masyarakat, ada beberapa faktor lainnya yang menyebabkan dampingan menjadi kurang percaya diri. Antara lain:

\section{Kurangnya perhatian dari orang tua.}

Selama berada di LKSA, pengurus merupakan orang tua pengganti dari dampingan. Dampingan yang berjumlah \pm 30 (tiga puluh) orang hanya diawasi oleh 6 (enam) orang pengurus menjadikan dampingan kurang perhatian secara penuh oleh pengurus. Posisi pengurus sebagai orang tua pengganti memang tidak bisa disamakan dengan perhatian orang tua kandung. Perhatian yang diberikan oleh pengurus hanya sewajarnya.

\section{Menerima keadaan.}

Tidak semua dampingan mampu menerima keadaannya saat ini. Pengalaman masa lalu serta trauma membuat dampingan semakin terpuruk. Mengajak untuk selalu mengingat Tuhan merupakan salah satu cara agar dampingan dapat menerima keadaan yang sekarang dan bersyukur atas segala pengalaman hidup. Penerimaan terhadap dirinya sendiri memang memerlukan waktu yang tidak sebentar.

Ada kolerasi yang erat antara tingginya percaya diri terhadap nilai prestasi akademik di sekolah. Hal ini sesuai dengan penelitian yang sebelumnya pernah dilakukan oleh Lisa Fatmala, dkk dalam artikelnya yang berjudul Hubungan Antara Kepercayaan Diri dengan Prestasi Belajar Kelas VII yang diterbitkan dalam jurnal Universitas Lampung.

Rasa tidak percaya diri ternyata merupakan sikap yang paling merugikan dan menunjukkan sikap ketidakcakapan seseorang. Terbentuknya kemampuan percaya diri adalah suatu proses belajar bagaimana merespon berbagai rangsangan dari luar dirinya melalui interaksi dengan lingkungannya. (Hendra Surya, 2007). Membentuk percaya diri terhadap anak, dapat dimulai dengan membentuk harga diri. Menurut Ilhamudin, Mualifah menyebutkan beberapa tips yang dapat dilakukan untuk menumbuhkan rasa percaya diri pada anak, antara lain: menghilangkan pengaruh negatif yang terjadi pada anak, memberikan pengakuan dan penghargaan, memberi pujian, memanjakan diri anak, beranggapan baik terhadap diri sendiri, mendapatkan input positif dari panca indera, dan membiasakan bersikap positif.

Berdasarkan pernyataan diatas, bahwa sikap percaya diri pada anak dapat dilatih 
dan kembangkan. Bahwa rasa percaya diri pada anak bukan berasal dari bawaan lahir, tetapi sikap percaya diri dapat dibentuk dan dibangun melalui proses yang dilakukan secara bertahap serta perlu dukungan dari semua pihak. Mengaingat sikap kurang percaya diri pada dampingan disebabkan oleh beberapa faktor yang berbeda, maka untuk memecahkan masalah tersebut pun berbeda.

Sikap percaya diri dapat ditumbuhkan dalam diri setiap anak. Hal tersebut menjadi pedoman bagi pendamping untuk dapat membangun sikap percaya diri pada dampingan sehingga prestasi akademik/belajar di sekolah meningkat.

Membangun rasa percaya diri akan berdampak besar terhadap: keyakinan diri, kesehatan dan kesejahteraan, hubungan dekat, keluarga, persahabatan, dan kehidupan pekerjaan. (Ros Taylor, 2003). Artinya bahwa kepercayaan diri merupakan kunci kesuksesan untuk masa depan. Mengingat pentingnya sikap percaya diri pada dampingan, maka program pengabdian dilakukan dengan tujuan utama agar dampingan memiliki sikap percaya diri, sehingga prestasi belajar di sekolah meningkat dan dapat dijadikan modal untuk dapat menjadi orang sukses di kemudian hari.

Oleh karena itu, program pengabdian tersebut adalah membuat kreativitas majalah dinding (mading) sekolah.
Pendamping bekerjasama dengan sekolah agar hasil karya dampingan dapat dipajang di mading sekolah. Mading dianggap sebagai media yang tepat untuk dapat menunjukkan kepada guru maupun teman sebaya mengenai kreativitas yang dimiliki oleh dampingan. Setidaknya ada 3 (tiga) sekolah yang bersedia menerima hasil kreativitas anak didiknya. Sekolah tersebut merupakan sekolah dimana dampingan belajar.

Mading yang dibuat oleh dampingan, ingin menunjukkan kepada pembaca bahwa anak yang tinggal di LKSA juga memiliki kemampuan untuk berkreativitas melalui ide-ide yang dituangkan di dalam mading dan tidak semua anak yang tinggal di LKSA bermasalah. Hal inilah yang menjadi pokok utama, dampingan ingin merubah stigma yang berkembang di masyarakat melalui kreatifitas. Segala produk yang dihasilkan dari proses kreatif dianggap sebagai produk kreatif dan orangnya disebut sebagai orang kreatif (Nugroho J. Setiadi, 2016).

Pendamping membantu dampingan berpikir kritis untuk memilih isi atau konten yang tepat untuk dijadikan sebagai bahan mading serta mempersiapkan bahan yang akan dijadikan hiasan dalam mading, baik barang bekas maupun barang baru. Ada berbagai tema yang dibuat dalam mading, antara lain tema "Indonesiaku". Tema tersbut diangkat menjadi bahan 
mading dengan tujuan untuk menggambarkan beragamnya kebudayaan di Indonesia.

Dengan banyaknya budaya di Indoesia diharapkan pembaca mading dapat saling menghargai satu dengan lainnya. Tema tersebut diambil mengingat bahwa dampingan kebanyakan berasal dari Indonesia Timur dimana memiliki budaya yang berbeda dengan masyarakat Jawa.

Selain tema mengenai keragaman Indoensia, mading sekolah yang dibuat dampingan juga berisi informasi mengenai “Anak Panti”. Siapa anak panti - apa kegiatan keseharian dan sebagainya. Isi atau konten dalam mading berupaya atau bertujuan agar masyarakat yang membaca mading tersebut menjadi tersadar dan terbuka wawasannya, bahwa anak yang tinggal di LKSA juga memiliki hak yang sama dalam berkehidupan di Indonesia.

Adanya pujian dan penghargaan dari guru serta teman sebaya membuat rasa bangga dalam diri muncul. Respon positif inilah yang menjadikan dampingan berkeinginan untuk terus membuat mading sekreatif mungkin dan memberikan konten mading yang bermanfaat bagi guru maupun teman sebaya. Hal ini juga yang menjadi pematik timbulnya rasa percaya diri bagi dampingan. Meskipun belum menunjukkan hasil yang maksimal dalam peningkatan prestasi, namun tingkat percaya diri dampingan sudah menunjukkan peningkatan.

Perkembangan yang dapat dilihat secara langsung adalah munculnya semangat dalam diri dampingan. Perubahan sikap dampingan antara lain: mulai munculnya keberanian untuk bertanya kepada pendamping ketika bimbingan belajar, munculnya sikap kerjasama antar dampingan dan semangat belajar meningkat. Tentunya sikap percaya diri ini perlu selalu di tingkatkan melalui berbagai program-program lain yang dapat mendukung. Mengingat bahwa waktu kegiatan KKN hanya 3 (tiga) bulan, pendamping mengharapkan kegiatan penanaman rasa percaya diri terus dilakukan hingga dampingan juga mampu memberikan hal positif bagi orang lain atau adik tingkat di LKSA.

\section{KESIMPULAN}

Berdasarkan pada uraian diatas, dapat disimpulkan bahwa rasa percaya diri dapat ditumbuhkan, karena rasa percaya diri bukan bawaan dari lahir. Melalui kreatifitas mading, dampingan dapat mengekspresikan ide dan kreatifitas. Isi atau konten dalam mading dapat dijadikan sarana komunikasi non verbal untuk memberikan pesan kepada pembaca mengenai sisi baik atau positif dari anak yang tinggal di LKSA. 
Penghargaan dan pujian yang diterima merupakan salah satu respon positif bagi dampingan. Melalui penerimaan tersebut, akan muncul kepercayaan diri. Bahwa kepercayaan diri merupakan modal agar dampingan menjadi orang yang sukses di kemudian hari.

$$
\text { Melalui kreatifitas mading, }
$$
dampingan menjadi lebih percaya diri. Sikap yang secara nyata ditunjukkan merupakan hasil atau dampak telah tumbuhnya rasa percaya diri pada dampingan. Hal ini harus terus di jaga, baik oleh pengurus LKSA, guru sekolah maupun teman sebaya.

\section{DAFTAR PUSTAKA}

Taylor, Ros (2003). Kiat-kita Pede. Jakarta: Gramedia.

Surya, Hendra (2007). Percaya Diri Itu Penting: Peran Orang Tua Dalam Menumbuhkan Percaya Diri Anak. Jakarta: Elex Media Komputindo

Setiadi, J. Nugroho (2016). Membangun Karakter Orang-orang Yang Sangat Kreatif. Yogyakarta: Gosyen Publishing

Qamar, Nurul (2013). Hak Asasi Manusia dalam Negara Hukum (Human Rights in Democratiche Rechtsstaat). Jakarta: Sinar Grafika. 